\title{
CHANGING TOURISM MARKETING STRATEGY OF TURKEY FOR THE LAST 10 YEARS
}

\author{
A. Nurdan Tümbek Tekeoglu ${ }^{1}$
}

\begin{abstract}
Tourism is one of the main income resources of Turkey and it increased to 34 billion 305 million 904 thousand USD in 2014 compared with 2013. It means 6,2 percent increase compared with 2013's figures. The increasing number of luxurous and modern hotels, the restoration and renovation of churchs and their opening to worship, increasing number of international conferences and meetings, the export of Turkish serials to many countries all over the world, the developing facilities of internet for booking, increasing numbers of tourism blogs and web sites, the special interest and strong communication of the government and other institutions to other regions like Middle East and Africa, increasing number of marinas, strong advertising and PR campaigns of Turkish Airlines and the government, the promotion of new destinations in Turkey, many marinas,attracting gastronomy possibilities are only few factors of the changing marketing strategy of Turkey.This paper is explaining the new strategic approachs to tourism and its results in the last 10 years.
\end{abstract}

Key words: Tourism, Tourism in Turkey, marketing strategy

\section{CHANGE OF THE MARKETING STRATEGIES OF TOURISM}

The great interest of the human beings to see and learn new places is leading people to travel from economic,ciltural or other reasons. Paralel to the economic and social developments, the increasing income level, the developments of the communication and information technology, less working hours and the increasing holiday periods effected the tourism sector and it became international (Artun, 2013, s. 1).

In such an international atmosphere the tourism sector should satify the demands of the tourists and also there should be an industrial structure. The industry side of tourism doesn't include accommodation and travelling servicesa (Altan 2009, s. 34). There should be also marketing of the products and services the tourists demand, the superstructure and infrasturcture investments should be realized. All these prove the growing and industrial dimensions of the tourism dimension. This dimension has more international characteristic (Soyak, 2013, ss. 4-5).

The tourism sector plays an important role for the cultural and economical development of related countries and owns a potential for the protection and development of the social,cultural and economical heritage (Smith, 1995, s.46). Based on that fact the tourism should be supported and it is the responsibility of the state and the other factors in the industry to keep dynamism of the tourism sector (Duru 2008, s. 62). The support should be continious, not periodic and the tourism sector should provide the profit that is expected by the tourism actors by increasing earnings so that the obligations realted with tourism industry are fulfilled.

The above mentioned developments and the increasing profit expectation warned people of this industry for more planned communication and marketing efforts as the limited tourism marketing mentality should be brought to a more developed level by using the technology factors both in national and international arena (Beyazgül 2009, s. 44).

\footnotetext{
${ }^{1}$ Assistant Professor, Beykent Üniversitesi, Ayazaga Maslak Yerleşkesi, Turkey.
} 
Especially the international tourism industry is marketing all the goods and services as a package after all the changes in the world. Thus, many sub factors of the tourism industry as tour operators, transportation companies, travel agencies,rent a car companies, food and beverage sector and hotels became international and a large-scale supply chain was built (Soyak, 2013, s. 5).

The mass tourism spurs the international tourism sector and the tourism sector is restructuring itself and looking for new marketing methods with the developments of internet and the information technology in 1990's anda t the same time with the new economical developments and the impulses of the tourism sector coming from itself (Toureg, 2009, s.10).

The information technology is providing the information infrastructure of the tourism sector and at the same time simplifies the purchasing of the new tourism destinations. Technology and innovation in the tourism sector provides a competitive advantage with the new marketing channels as promotion, distribution, regulation and providing of touristic products to the consumers and usage of the resources rationally. (Karataş ve Babür 2013, s. 15).

With the developments of the economical structure based on the globalization increased the importance of the customer oriented services(Bağdat, 2007, s. 39). Among them is tourism, which is providing for the clients at the top level. Therefore tourism sector should plan all the marketing activities not only during the tourism season but also before the tourism season during the decision making period of the clients. (Çekiç 2007, s. 55).

Consumers in tourism sector are using all the possibilities given to them by the new economy and give the decision fort he best product or service suitable fort hem. They learn all about the product price, characteristics and how to reach. The tourism companies always define their target groups, their consumption demands and create their product mix (Karataş ve Babür 2013, s. 19). There are interactive and more effective promotional activities in the electronical media. Especially the websites became very important channels for the tourism stakeholders to promote themselves(Altan 2009, s. 49).

The information and communication technologies transform the activities of the tourism corporations, their communication methods and also the purchasing ways of the purchasing of the touristic goods and services(Bağdat, 2007: 40). The main reason is the possibility to realize interactive marketing activities to more target groups in limited time to provide time saving as the tourism is seasonal and provide limited time period for marketing(Terzioğlu 2010, s. 81).

Therefore the tourism sector is trying to make use of all the technological changes and developments. Informationa and detail is very important for the tourism sector and everybody in the sector welcomes the usage of it for the marketing activities (Kilimci 2009, s. 34).

Touristic services are intangible, therefore there is o chance to try before buying it. Therefore the marketing, communication and explanation of the touristic services have to be made very clearly. The satisfaction of the consumer is only possible through very actual and correct information exchange (Karataş ve Babür 2013, ss. 19-20). Therefore interactive applications are very necessary.

Below are the trends effecting the marketing activities and it's development and change (Karataş ve Babür 2013, s. 20):

- New emerging international competitors with the new global economy,

- With the increasing prosperity new competitors and actors in the supply chain of the tourism industry and others sectors, 
-New fast changing socio-economic structure and continious consumer demands,

- Tourism demand with the changing life styles ( hysterical travels, adventure trips or education oriented tours),

- With increasing income level more satisfaction expectations and more looking for harmony and value added services and expectation for more tailor made touristic solutions, - More conscious consumers eager to learn more with the help o fthe developed information Technologies (direct marketing is more convenient for these clients),

- More usage of the communication products by the tourism consumers because of the increase of the interest and practice of the information Technologies.

Most of the tourism companies making their communication through the internet reach more people in a limited time and they design their own web pages and have the advantage of informing the consumers in a more detailed way and they also make it possible to make one's own reservations with the help of the web sites (Şahin ve Akdoğdu, 2004: 4).

The technological channels give the tourism actors the chance to evaluate their activities based on the information they collected from the consumers and give the necessary background to decide the direction fort the new investments. All these motivate the tourism industry players to realize sustainable activities and make their marketing activities accordingly (Döner 2011, ss. 54).

The distribution channels of the tourism sector make more and more use of the communication and information technologies Marketing success is only possible by defining the right product or service at the right place and with the right distribution channels. Ditsribution is getting easier evryday by the communication and information Technologies and with this cost advantage is obtained and a mutual communication is provided betwwen the ones buying the touristic products and the target markets (Karataş ve Babür 2013, s. 20).

Advantages of the technology to the actors of the tourism industry are as the following (P1rnar, 2005: 71):

- Easy access to thousands of database and documentation centre to investigate about the data related with the tourism sector through the internet,

- Reaching the targetted information by specific shortening and concentration on specific topics among unlimited information,

- Easiness for following and evaluation of statistics for special target groups with special demographical characteristics,

- Fastness and easiness while sharing, building and distribution of the information,

- Interactive communication with the clients and other groups related with the sector,

- Actualization convenience of the existing data and information,

- Fastness,effectivtiy and productivity by e-mailing,

- Reduction of traditional marketing costs,

- Easiness for raeching national and international demographic markets,

- Fastness and effectivity at the application of the new campaigns,

- Cost saving by shortening the communication period,

- Easiness to measure the obtained results,

- Feedback possibility from the target groups,

- Development of the company image and impact effect,

- Possibility to prepare presentations,company catalogues and brochures at the internet,

- Easiness to reach international media during the communication activities

- 24 hour communication,

- Dissolution of the continental,regional and geographical obstacles 
- To be able to be acquainted with the competitors following the new technologies.

Every stakeholder of the tourism sector has to use the technology. The development of the tourism sector is more up to the steps mad efor marketing via the electronical media. Communicating through the electronical media provides to the tourism sector with cost saving and as the tourism sector is effected by the economical crises all over the world heavily, all the actors of the sector take electronical media into account (Gürsey ve Parla 2012, s. 44).

As the technology supported the marketing activities of tourism new tourism activity fields have been created. The new channels created by the socio-cultural developments, the attractiveness of various organizations and spaces related with famous names are only a few factors of the tourism marketing world. Every factor has a great effect to attract people to a certain destination. (Döner 2011, ss. 54).

Television and internet create new tourism areas with their continious changing content.Documentaries, sport organisations, meetings, fairs and exhibitions are all seen as a marketing tool by the stakeholders of the tourism industry to attract the attention of the consumers (Gürsey ve Parla 2012, s. 46). Each and every organisation organised for the actors of the tourism and each emerging socio-cultural fact means broading of the market.

The stakeholders of the tourism sector sponsor the above mentioned organisations to create new tourism channels and discovery of new ways for touism marketing. Sea,hotel and historical monuments are not enough for tourism: all the factors except these created by the popular culture are effective means for marketing and the tourism sector give big efforts to use them(Mutlu 2010, ss. 73).

Beside the marketing advantages of the technolgy there is a differentiation of the tourism products. This differentiation emerge from the different interest areas of the consumers. More different promotions are needed in the name of tourism where there is a severe competition among the increasing number of tourism companies and efforts have to be given to create more earnings for more stakeholders of the tourism (Kilimci 2009, s. 84).

Finding of the research based on the evaluation of the interviews of 67 tourism actors that are in tourism sector for more than 10 years support the subjects in this paper. The most important finding of the research is that the Turkish serials effected the pomotion of Turkey abroad.Some thematic serials effected people in and outside the country to prefer Turkey for their holiday. The fact that the serials are also followed in electronical media created a new tourism marketing channels for Turkey.

Another noteworthy finding is the increasing transportation possibilities to the historical and tourism places. Accordingly the state and other tourism actors made the necessary attempts to attract the tourists to different tourism destinations. The transportation to the tourism destination is promoted by the stated.

Another finding which respondents supported strongly is that the promotional activities for conferences, fairs and exhibitions, meetings, seminars, shopping, sports competitions, environmental trips, edutacational possibilities increased remarkably. Each and every actor in the tourism sector finds itself a new field in the above mentioned spectrum to promote and diversify his activities.

And lastly the high agreeing to the increase of the luxurious hotels proves that accommodation under good conditions is an important means to be able to attract tourists to a country. Electronical media simplifies both information exchange and choosing between different alternatives for the tourists 
Another interesting point of the research is the increase of the tourists from the Middle Eastern countries and the increasing interest level to the tourism products in Turkey. The incentive organizations and the socio-economic developments had positive effect on the Middle-eastern population.

\section{CONCLUSION}

The tourism sector is sensitive due to the changing purchasing power of people according to the global economical developments. This interaction influenced each and every actor in the tourism sector in the last 20 years. But the tourism sector is following the latest developments all around the world and has taken measures by creating new spaces to itself. Thus in today's world the tourism sector isn't effected much by every new development in the world and it is surviving strongly.

This surviving was only possible through strong marketing structures. All the actors of tourism has the chance to communicate and market its activities all around the world by the technology.

Actors of tourism left the traditional advertising tactics as brochure or newspaper advertising and used all the means of technology and internet is attracting everyone because of its practical and profitable solutions for more earnings.

The marketing perception is being changed according to the solutions that the technology provides and thus the tourism world is finding itself new marketing channels, new clients and new business partners. Technology is also serving to tourism as it is serving to many other sectors and makes it possible to reach people to be able to promote or market different activities, products and services.

Beside the technology all the socio-economical developments and sport based organisations and many others in the world are important for marketing the tourism sector. All the steps made to make profit makes the several sports organizations or others important to open new tourism channels..Every organisation during the year causes travelling of clients to a destination and supports touristic activities. Thus actors in the tourism sector create themselves new markets by investigating the possible tourism service aspects at these organisations.

Finding of the research based on the evaluation of the interviews of 67 tourism actors that are in tourism sector for more than 10 years support the subjects in this paper. The most important finding of the research is that the Turkish serials effected the pomotion of Turkey abroad.Some thematic serials effected people in and outside the country to prefer Turkey for their holiday. The fact that the serials are also followed in electronical media created a new tourism marketing channels for Turkey.

Another noteworthy finding is the increasing transportation possibilities to the historical and tourism places. Accordingly the state and other tourism actors made the necessary attempts to attract the tourists to different tourism destinations. The transportation to the tourism destination is promoted by the stated.

Another finding which respondents supported strongly is that the promotional activities for conferences, fairs and exhibitions, meetings, seminars, shopping, sports competitions, environmental trips, edutacational possibilities increased remarkably. Each and every actor in the tourism sector finds itself a new field in the above mentioned spectrum to promote and diversify his activities.

And lastly the high agreeing to the increase of the luxurious hotels proves that accommodation under good conditions is an important means to be able to attract tourists 
to a country. Electronical media simplifies both information exchange and choosing between different alternatives for the tourists

Another interesting point of the research is the increase of the tourists from the Middle Eastern countries and the increasing interest level to the tourism products in Turkey. The incentive organizations and the socio-economic developments had positive effect on the Middle-eastern population.

\section{REFERENCES}

Sezgi Terzioğlu, Küreselleşen Dünyada Turizm, Sözbir Basım Yayım, Ankara, 2010.

Artun, E., "Halkın Kültürünün Uluslararası İlişkilerde Ülkelerin Tanıtımına Katkısı", http://turkoloji.cu.edu.tr/HALKBILIM/60.php, (Erişim Tarihi: 02.03.2013).

Nuran Beyazgül, Dünyada Güçlenen Sektörler ve Turizm Sektörü, Arslan Yayınları, İstanbul, 2009.

Smith, S. L. J., Tourism Analysis, Longman, Harlow, England, 1995.

Aybars Kilimci, Turizmin Değişen Çehresinde Popüler Kültür Etkisi, Turizm Sektörel Analiz, Sayı: 21, 2009, ss. 33-42.

Toureg-Innovation and Tourism Knowlodge, Global Swot Analysis, October, 2009.

Tuğba Mutlu, Turizmde Değişim ve Dönüşüm: Yeni Mecralar, Yeni Pazarlama Teknikleri, Turizm Yatırımcıları Derneği Dergisi, No: 17, 2010, ss. 71-78.

Bağdat, B., (2007): Yeni Ekonomi ve Yeni Ekonominin Temeli Olan İnternetin Konaklama İşletmeleri Üzerindeki Etkisi ve Bodrum Yöresi'nde Bir Uygulama. Yayımlanmamış Yüksek Lisans Tezi. Dumlupınar Üniversitesi Sosyal Bilimler Enstitüsü, Kütahya.

Emre Duru, Turizm İşletmeciliği ve Turizmin Küresel Evrimi, Etiket Basım Yayım, İzmir, 2008.

Şahin. M. ve Akdoğdu P. (2004). Bilişim Teknolojilerindeki Gelişmelerin Turizm Sektörüne Etkisi ve Kullanım Alanları, 2.Ulusal Bilgi, Ekonomi ve Yönetim Kongresi. İzmit: Kocaeli Üniversitesi: 343-352. www.projepelit.com/proje3/kaynaklar/MAKALE\%205.doc (24.10.2011).

Pırnar, I. (2005). Turizm İşletmelerinde Etkin Yönetim ve Çağdaş Pazarlama, İktisat İşletme ve Finans Dergisi, Y11:20, Sayı:235, Ekim.

Efkan Naim Çekiç, Turizm ve Ekonomi, Telgraf Yayıncılık, Ankara, 2007,

Münevver Soyak, ULUSLARARASI TURIZMDE SON EĞİLIMLER VE TÜRKIYYE'DE TURIZM POLITIKKALARININ EVRIMI, Marmara Sosyal AraĢtırmalar Dergisi The Journal of Marmara Social Research, Say1 4, Haziran 2013, SS. 1-18.

Fevzi Gürsey ve Tarık Parla, Global Turizmde Yeni Trend: Organizasyonel Pazarlama, AR-GE Kurumsal, Say1: 13, 2012, ss. 42-46.

Sezer Altan, Turizm Pazarlaması, İlkel Yayıncılık, Ankara, 2009.

Muhammed KARATAŞ, Serap BABÜR, Gelişen Dünya'da Turizm Sektörünün Yeri, KMÜ Sosyal ve Ekonomik Araştırmalar Dergisi 15 (25): ss. 15-24, 2013.

Soyak, A., "Turizm Sektöründe Bağımlılığın Sonuçları ve Politika Önerileri 2", içinde, Ekonomi ve Politikada Ulusal Tavır, Derin Yayınları, İstanbul, 2011, ss.103-106.

Yalçın Döner, Teknoloji Kullanımı ve Turizm Pazarlamasında Teknoloji Desteği, Kurumsal Pazarlama Dergisi, No: 19, 2011, ss. 51-57.

Tekeoğlu, N., The Investigation Of The Change In Marketing Strategies In Tourism

Sector, JASSS, The Journal of Academic Social Science Studies, 2015 